
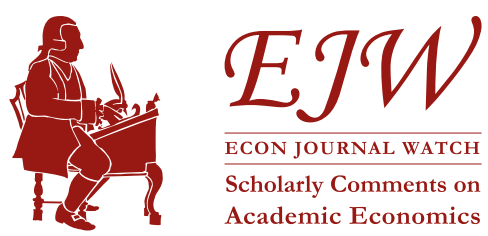

ECON JOURNAL WATCH 16(1)

March 2019: 146-154

\title{
Edmund Burke as an Economist
}

\author{
Donal Barrington
}

\section{LINK TO ABSTRACT}

"The age of chivalry is gone: that of sophisters, economists, and calculators, has succeeded; and the glory of Europe is extinguished forever."1

It seems almost sacrilegious to accuse the writer of this famous passage of being an economist himself, and not many people have attempted to do so. The romantic language in which Burke has clothed much of his philosophy might lead one to imagine that he was not interested in the ordinary affairs of mankind, and as economics is concerned with very little else, that he was not interested in economics. Indeed, Melchior Palyi, discussing the relation between Burke and Adam Smith, wrote, "their ideas, their methods, even their problems, were decidedly different, as different as the men themselves and their personal careers."2

Such an impression is false. One can over-emphasise the romantic element in Burke. In fact he was so concerned with the happiness of ordinary men and women that some writers have called him a utilitarian. That, I think, is putting the point too strongly, but utilitarianism was an important factor in his political philosophy.

Moreover, an interest in the nobler and more spiritual aspects of man's nature does not preclude one from being acquainted with the manner in which he earns his bread. Indeed the career of Lord Keynes shows that one can become a great economist through sheer annoyance at man's having to spend so much time earning his living.

Burke had a sound grasp of the central principles of political economy. He

a. This article was originally published in Economica, n.s. vol. 21 no. 83, pp. 252-258, (C) 1954 London School of Economics. It is reprinted here with kind permission from John Wiley \& Sons, Inc.

1. Works (Little and Brown), Boston, 1839, (9 Vols.), Vol. III, p. 98.

2. "The Introduction of Adam Smith on the Continent," in Adam Smith, 1776-1926, by John Maurice Clark and others, p. 181; see also an article by W. C. Dunn, "Adam Smith and Edmund Burke: Complementary Contemporaries," in The Southern Economic Journal, January 1941, Vol. VII, No. 3, p. 330. 
was the first great English statesman to preach Free Trade and he is entitled to be considered as one of the pioneers of economic science.

How Burke acquired his great knowledge of economics is not easy to explain. But it is not much more difficult to account for his grasp of this subject, than it is to trace the origins of his vast knowledge of almost every other branch of human learning. "Single speech" Hamilton, who employed Burke for six years, from 1759 to 1765 , as "companion" in his studies, said of him that he understood everything in the world except music and gaming. ${ }^{3}$ On another occasion Hamilton remarked to a friend that, though he himself was a Lord of Trade, though he had access to all the official documents, and though he had studied them conscientiously, nevertheless he felt at a loss when talking to Burke, so great was Burke's knowledge of this subject. ${ }^{4}$

Burke probably spent part of his six years with Hamilton studying political economy. ${ }^{5}$ But long before this, while still a student in Trinity College, Dublin, he seems to have envisaged that the scattered principles of economics could be gathered together into a definite science. In The Reformer he lamented the sad condition of Irish trade and suggested that the nobility should patronise the study of trade just as they patronised the other branches of learning. Burke approved of the activities of bodies like the Dublin Society but thought that it was also necessary for private individuals to take up the study of trade as a definite branch of learning:-

"Nothing comes to its height at first, and the Spirit of encouraging Trade, may at length rise to Science. What has been done hitherto has been by Bodies of Men, few have had the courage singly to venture any Thing, tho' private Men have always been the Support of Works of Politeness."

This was written in 1748 when Burke was eighteen years old. Eleven years later, Dr. Markham, the headmaster of Westminster, writing to the Duchess of Queensbury to recommend Burke for the post of consul in Madrid, remarked that his chief application had been to the knowledge of public business and to the commercial interests of Great Britain; that he seemed to have a most extensive knowledge, with extraordinary talents for business, and to want nothing but ground to stand upon to do his country very important services. ${ }^{7}$ Some years later the "allknowing" Jackson said to Dr. Johnson that his "Journey to the Western Islands of

3. Sir Philip Magnus, Edmund Burke, p. 17.

4. Edmund Burke, Thoughts and Details on Scarcity, London, 1800, Preface, p. VI.

5. Bertram Newman, Edmund Burke, London, 1927, p. 19.

6. The Reformer, No. 6, reproduced in Samuels' Early Life of Burke, p. 314.

7. Prior, Life of Burke, 5th ed., London, 1884, pp. 62-3. 
Scotland" contained more good sense about trade than would be heard for a whole year in Parliament "except from Burke.",

On his entry to Parliament in 1766 Burke had quickly established a reputation for himself as an expert on problems relating to trade and commerce. Shortly after his first speech, General Lee wrote to the Prince Royal of Poland that an Irishman, one Mr. Burke, had sprung up in the House of Commons, who had astonished everybody with the power of his eloquence, his comprehensive knowledge of all the exterior and interior politics of Great Britain and of her commercial interests.

In October 1766 the Duke of Grafton wrote to Chatham suggesting that they try to attach Burke to the Ministry by making him Lord Commissioner of the Board of Trade. Chatham rejected this suggestion. He admitted that Burke was a man of great ability, but considered that his views on trade were too unorthodox. "As to his notions and maxims of trade," he wrote, "they can never be mine. Nothing can be more unsound and repugnant to every true principle of manufacture and commerce, than the rendering so noble a branch as the Cottons, dependant for the first material upon the produce of French and Danish Islands, instead of British." ${ }^{\text {,10 }}$ The great debate on Free Trade had begun.

In his speech on his arrival in Bristol in 1774 Burke himself bore testimony to his economic studies. When first he devoted himself to the public service, he had considered how he should render himself fit for it: and this he did by endeavouring to discover what it was that gave England the rank she held in the world. He found that her prosperity and dignity arose principally, if not solely, from two sources, her constitution and her commerce. Both these he had spared no study to understand, and no endeavour to support. ${ }^{11}$

Many years later, when, in his "Letter to a Noble Lord," he was answering the attacks which the Duke of Bedford and the Earl of Lauderdale (the noted economist) had made on his pension, he wrote that he had not come into Parliament to con his lesson. He had earned his pension before he set foot in St. Stephen's Chapel. During his first session in Parliament he had found it necessary to analyse the whole commercial, financial, constitutional and foreign interests of Great Britain and its empire. ${ }^{12}$

He continued with the following most interesting passage:-

"Does his grace think that they who advised the crown to make my retreat

8. Boswell, Life of Johnson, Oxford edition, 1904, Vol. II, p. 105.

9. Lee to the Prince Royal of Poland, December 25th, 1766, in Lee's Memoirs, Dublin, 1792, p. 297.

10. Chatham to Grafton, October 19th, 1766, in Autobiography and Political Correspondence of Augustus Henry,

Third Duke of Grafton, ed. by Sir William Anson, London, 1898, p. 108.

11. Works, Vol. II, p. 4.

12. Works, Vol. IV, p. 298. 
easy, considered me only as an economist? That, well understood, however, is a good deal. If I had not deemed it of some value, I should not have made political economy an object of my humble studies, from my very early youth to near the end of my service in parliament, even before (at least to any knowledge of mine) it had employed the thoughts of speculative men in other parts of Europe. At that time it was still in its infancy in England, where, in the last century, it had its origin. Great and learned men thought my studies were not wholly thrown away, and deigned to communicate with me now and then on some particulars of their immortal works. Something of these studies may appear incidentally in some of the earliest things I published. The house has been witness to their effect, and has profited of them more or less for above eight and twenty years."13

The remark about the "great and learned men" who communicated with Burke on some particulars of their "immortal works" almost certainly refers to Adam Smith and the Wealth of Nations. The two men greatly admired each other. When Smith read Burke's essay on the "Sublime and Beautiful"- the first work which Burke published under his own name- - he remarked that the author would be a great acquisition to Glasgow University "if he would accept of a chair." ${ }^{14}$ Some time later, in the year 1759, Hume, who was attempting to popularise Adam Smith's Theory of Moral Sentiments in London, sent Burke a copy, pretending that the present had come originally from Smith. ${ }^{15}$ Burke was very much taken by the book and asked Hume for Smith's address. ${ }^{16}$ In the same year he reviewed the book very favourably in the Annual Register.

The Wealth of Nations was also reviewed in the Annual Register but we cannot be sure that this review was written by Burke. Burke was still in charge of the Annual Register in 1776 and was, in fact, still writing most of it. But he had an assistant, so that we cannot be sure that he wrote this particular review. On the other hand it is quite probable that he did, especially as Smith was a friend of his, and as he was so interested in economics. The style in which the review is written would also appear to support the theory that Burke wrote it.

The reviewer praises the work highly. He also shows himself to be acquainted with the writings of the Physiocrats. "The French œeconomical writers," he says, "undoubtedly have their merit. Within this century they have opened the way to a rational theory, on the subjects of agriculture, manufactures, and commerce. But no one work has appeared amongst them, nor perhaps could there be collected

13. Ibid, pp. 298-99.

14. Letter from Dugald Stewart to Sir James Prior in Prior's Life of Burke, p. 38, footnote.

15. Letters of David Hume, ed. by J. Y. T. Greig, Oxford, 1932, Vol. I, p. 303.

16. Ibid., p. 312. 


\section{BARRINGTON}

from the whole together, anything to compare with the present performance, for sagacity and penetration of mind, extent of views, accurate distinction, just and natural connection and dependence of parts." ${ }^{\text {17 }}$

Burke and Smith may have met as early as 1759. Certainly they knew each other by 1775 when Smith was elected a member of Dr. Johnson's Club. They became close friends and they saw a lot of each other during the two years Smith spent in London after the publication of the Wealth of Nations. Burke went to Glasgow in 1784, upon his election as Lord Rector of Glasgow University. He spent about ten days in Scotland. Where he stayed we do not know, but he certainly spent most of his time in the company of Smith, who was then Professor of Logic at the University. ${ }^{18}$

Bisset gives an account of an interview which a "very eminent literary gentleman" had with Burke shortly before the latter's death. Burke, it seems, spoke in very flattering terms of Smith, described him as a man of profound and extensive learning, and said that his work would be of great value. He added that Smith's heart had been "equally good with his head" and his manners "peculiarly pleasing." 19

Dr. Johnson did not consider an occasional sally into the economic field beneath him, and with Burke and Smith such keen students of economics, it seems strange that that subject was so seldom mentioned in the Club. Perhaps the reason was that Johnson strongly disliked Smith, while Smith had ample reason to resent Johnson's rudeness. ${ }^{20}$ Or perhaps it was that Johnson, who liked to argue for victory, preferred to avoid a subject about which Smith and Burke knew so much more than he did.

Burke and Smith being friends, it might seem reasonable to conclude that Burke borrowed his ideas on economics from Smith. No doubt Smith did influence him, but, nevertheless, Burke appears to have reached his main conclusions independently. We have seen that while still in college he had been interested in the study of trade, and that he himself claimed to have studied political economy long before, to any knowledge of his, it had engaged the thoughts of speculative men elsewhere in Europe. These claims are corroborated by a remark attributed to Smith. He is reported as having said that Burke was the only man he ever met who thought exactly as he himself did on economic problems without any prior communication having passed between them. ${ }^{21}$

Indeed, it would seem that Burke not only arrived at his conclusions indepen-

17. Annual Register, 1776, Part II, p. 241.

18. John Rae, Life of Adam Smith, London, 1895, p. 388.

19. Bisset, The Life of Edmund Burke, 2nd ed., London, 1800, Vol. II, p. 424.

20. John Rae, Life of Adam Smith, pp. 154-8.

21. Bisset, Life of Burke, Vol. II, p. 429. 
dently of Smith but that he actually assisted Smith on some points. Thomas Moore reports in his Memoirs an interesting remark of Wordsworth's. Wordsworth complained of the ignorance of politicians. Burke, however, he said, had been an exception. He was by far the greatest man of his age. Not only did he abound in knowledge himself, but he helped his most able contemporaries in almost every field of study, "assisting Adam Smith in his Political Economy and Reynolds in his Lectures on Painting.",22 Wordsworth's statement that Burke assisted Reynolds is correct, and his statement about Smith may also be accurate.

In fact it fits in very well with Burke's remark about the "great and learned men" who had discussed economic problems with him. But we have another piece of evidence. This is contained in the preface to an edition of Burke's Thoughts and Details on Scarcity which was published in 1800. This little pamphlet is the most important of Burke's economic writings, but it was not published during Burke's lifetime. In its original form it was a memorial which Burke presented to Pitt in 1795. Burke had intended expanding it into a series of Letters on Rural CEconomics addressed to Mr. Arthur Young. Unfortunately, he had hardly begun this task when he heard of the peace negotiations between France and England and he abandoned it to write his Letters on a Regicide Peace.

Upon Burke's death in 1797 his two most loyal disciples, Dr. French Laurence and Dr. Walker King, were entrusted with the care of his papers. ${ }^{23}$ Three years later the Thoughts and Details on Scarcity appeared. It consists of the memorial addressed to Pitt in 1795 expanded to include some fragments, which the editor had discovered, of Burke's proposed Letters on Rural CEconomics.

The editor does not give his name but the Preface is dated "Beaconsfield, Nov. 1, 1800." "Beaconsfield," of course, was the home of the Burke family, and it is more than probable that the editor was either Dr. French Laurence or Dr. Walker King. Of the two it is more probable that the editor was Dr. French Laurence as he is known to have been interested in economics. That Laurence was in fact the editor is virtually proved by a remark made in a letter quoted by Arthur Young in his Autobiography. The letter is dated November 30, 1800, and refers to Burke's pamphlet "very lately published by Dr. Lawrence." 24 Laurence is a very valuable witness because, as I pointed out already, he was one of Burke's most loyal and intimate disciples and was also interested in economic problems himself.

The preface speaks of Burke's vast knowledge of the British commercial system. It refers to the great reputation which he quickly won in Parliament as an

22. Moore, Memoirs, Journal and Correspondence (8 Vols.), London, 1853-56, Vol. III, p. 162.

23. Corr., Vol. I, Preface, p. III.

24. J. Symonds to the Speaker of the House of Commons, November 30th, 1800, in Young, Autobiography, London, 1898, pp. 344-46. 
expert on economic affairs. Yet, it continues, despite his early fame as an economist, he studied political economy all his life, and made use of every opportunity which turned up to examine the economic systems of other countries. As a result of these studies he daily became more convinced that the "unrestrained freedom of buying and selling is the great animating principle of production and supply.", 25 But, most important of all, the preface states that Burke was "consulted, and the greatest deference was paid to his opinions, by Dr. Adam Smith, in the progress of the celebrated work on the Wealth of Nations."26

Burke's economic ideas might have been expected to attract the attention of merchants and, in actual fact, they did. During the course of his career addresses of thanks poured in on him from nearly all the mercantile cities of Ireland and England, and he received the freedom of many of the most important centres of trade. His economic opinions also got him into difficulties, as when he lost his seat at Bristol largely through advocating Free Trade for Ireland.

It would serve no useful purpose to examine in detail the numerous addresses of thanks which Burke received. But it is perhaps worth while to have a glance at one specimen. The following is a portion of an address which the merchants of Lancaster sent to Burke in June 1766, six months after he entered Parliament:-

"Sir,

With hearts full of gratitude and respect, we, the merchants of Lancaster, beg leave to return you our most sincere thanks for the great attention you have given to the commercial interest of Great Britain and her colonies, during the last long and laborious session of parliament, both by removing obstructions that lay in the way of commerce, and opening new sources of trade, unknown in former times; from which we have the most sanguine hopes, that, in future, the manufactures and navigation of this kingdom will be greatly increased and extended. ..."27

I think we may safely conclude, therefore, that Burke had a considerable grasp of the principles of political economy; that he was a Free Trader; that he arrived at his conclusions independently of the work of Adam Smith; that Adam Smith respected his opinions on this subject and even consulted him on points; and that he is therefore entitled to be considered as a pioneer of economic science. Moreover, by his speeches in Parliament, he introduced the new principles of economics to the politicians of the day, and the amazingly rapid success of the

25. Thoughts and Details on Scarcity, London, 1800, Preface, p. VII.

26. Ibid., p. VI.

27. Corr., Vol. I, p. 104. 
Wealth of Nations may have been, in part, due to the fact that Burke had prepared men's minds for it.

\section{References}

Bisset, Robert. 1800. The Life of Edmund Burke, 2nd ed., 2 vols. London: Cawthorn.

Boswell, James. 1904 [1799]. Life of Johnson. London: Henry Frowde.

[Burke, Edmund]. 1776. Review of An Enquiry into the Nature and Causes of the Wealth of Nations by Adam Smith. Annual Register 19: 241-243.

Burke, Edmund. 1839. The Works of Edmund Burke, 9 vols. Boston: Little and Brown.

Burke, Edmund. 1844 (Corr.). Correspondence of the Right Honourable Edmund Burke., ed. Charles William, Earl Fitzwilliam, and Richard Bourke, 4 vols. London: Francis \& John Rivington.

Burke, Edmund. 1923 [1748]. The Reformer, No. 6. In The Early Life Correspondence and Writings of the Rt. Hon. Edmund Burke LL.D., by Edmund Burke and Arthur P. I. Samuels, 312-314. Cambridge, UK: Cambridge University Press.

Chatham, William Pitt, Earl of. 1898 [1766]. Letter to Grafton, October 19. In Autobiography and Political Correspondence of Augustus Henry, Third Duke of Grafton, ed. Sir William R. Anson, 108-109. London: John Murray.

Dunn, William Clyde. 1941. Adam Smith and Edmund Burke: Complementary Contemporaries. Southern Economic Journal 7(3): 330-346.

Hume, David. 1932 [1759]. Letter to Adam Smith, April 12. In The Letters of David Hume, vol. 1., ed. J. Y. T. Greig, 303-306. Oxford: Oxford University Press.

[Laurence, French]. 1800. Preface to Thoughts and Details on Scarcity, by Edmund Burke, iii-xvi. London: F. and C. Rivington.

Lee, Charles. 1792 [1766]. Letter to the Prince Royal of Poland, December 25. In Memoirs of the Life of the Late Charles Lee, 295-299. Dublin.

Magnus, Philip. 1939. Edmund Burke: A Life. London: John Murray.

Moore, Thomas. 1853-1856. Memoirs, Journal and Correspondence of Thomas Moore, 8 vols., ed. Lord John Russell. London: Longman, Brown, Green, and Longmans.

Newman, Bertram. 1927. Edmund Burke. London: G. Bell \& Sons.

Palyi, Melchior. 1928. The Introduction of Adam Smith on the Continent. In Adam Smith, 1776-1926, by John Maurice Clark, Paul H. Douglas, Jacob H. Hollander, Glenn R. Morrow, Melchior Palyi, and Jacob Viner, 180-234. Chicago: University of Chicago Press.

Prior, James. 1884. Life of the Right Honourable Edmund Burke, 5th ed. London: George Bell \& Sons.

Rae, John. 1895. Life of Adam Smith. London: Macmillan.

Stewart, Dugald. 1884 [n.d.]. Letter to James Prior. In Life of the Right Honourable Edmund Burke, 5th ed., by James Prior, $38 \mathrm{n}$. London: George Bell \& Sons.

Symonds, J. 1898 [1800]. Letter to the Speaker of the House of Commons, November 30. In The Autobiograpby of Arthur Young, With Selections from His Correspondence, by Arthur Young, ed. Matilda Betham-Edwards, 344-346. London: Smith, Elder \& Co. 


\section{About the Author}

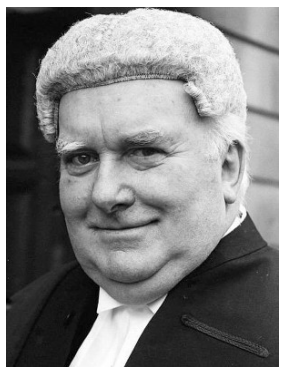

Donal Barrington (1928-2018) was a barrister and judge. He was a member of the Supreme Court of Ireland from 1996 to 2000, and after retirement from the Court he served as the first president of the Irish Human Rights Commission. Barrington studied law at University College Dublin, where he wrote a master's thesis on Edmund Burke. He was an active entrepreneur in civic life, helping to found the think tank Tuairim in 1954 and the watchdog Irish Council on Civil Liberties in 1976. An obituary in the Irish Times says that during his legal career he "achieved a cast-iron reputation as an advocate for whom constitutional rights, particularly when under threat, were of primary concern." On the occasion of his being awarded an honorary degree by the National University of Ireland, the introductory speech stated that "His social concern for great principles is matched by his empathy for individuals and their idiosyncrasies."

Go to archive of Watchpad section Go to March 2019 issue 